\title{
The Influence of Organizational Commitment, Auditor Independence, Internal Control, and Ethical Leadership in Good Governance and Organizational Performance
}

\author{
Cornelius Rantelangi ${ }^{1}$, Nurita Affan ${ }^{2}$, Dwi R Deviyanti ${ }^{3}$, Wulan I R Sari ${ }^{4}$ \\ Faculty of Economics and Business, Mulawarman University, Indonesia \\ ${ }^{1} \mathrm{co}$. rantelangi@gmail.com \\ ${ }^{2}$ nurifa.affan@feb.unmul.ac.id \\ ${ }^{3}$ dwi.risma.deviyanti@feb.unmul.ac.id \\ ${ }^{4}$ wulan.sariefeb.unmul.ac.id
}

\begin{abstract}
Indonesia public sector faces new public management problems, such as good governance since reformation era. This is because there is dynamic changing in public sector organization. In contrast, processes of individual and organization improvement are rising up lately. Thus, this study aims to empirically examine the effect of organizational commitment, auditor independence, internal control, and ethical leadership in good governance and organizational performance. A quantitative approach is used in this study by collecting primary data.

Results show organizational commitment, auditor independence, and ethical leadership significantly influences the implementation of good governance. While the internal control do not significantly affect the application of good governance. In this study also found that organizational commitment, good governance implementation has direct and significant impact on the performance of the organization. Ethical leadership directly affects organizational performance but not significantly. While internal controls had no significant effect on the performance of the organization with coefficient $-\mathbf{0 . 1 4 0}$. In short, to strengthening public sector organization, it needs good governance, organizational commitment through ethical leadership.
\end{abstract}

Keywords - governance, organizational commitment, auditor independence, leadership, and performance.

\section{INTRODUCTION}

Good governance that running well will be able to produce good organizational performance as well. Performance itself can be explained as a picture of the achievement of the implementation of an activity or a program or a policy in realizing the means, goals, mission, and vision of the organization. In general, performance is an achievement achieved by the organization within a certain period. Therefore, performance measurement needs to be done to measure the achievement of the activity because the measurement or performance appraisal is the process of recording and measuring the achievement of the implementation of activities [1].

Good governance is crucial in improving local government performance. As a crucial matter, good governance in the local government should be improved. To improve the implementation of good governance, it is necessary to analyze the factors that support the implementation of good governance in government institutions. Factors affecting the implementation of good governance include social variables (population, democracy, education level) and economy (budget) [2], leadership [3]-[4], organizational commitment [3], internal control [5]-[6] and auditor independence [5].

This study focuses on organizational commitment, auditor independence, internal control and ethical leadership in the implementation of good governance and organizational performance. This is because to understand those factors work in good governance and organizational performance, development understanding from individual perspective to organizational perspective is needed. Organizational commitment is the degree to which individuals believe in and accept organizational goals and are willing to always be with the organization [7]. Organizational commitment is also defined as a statement in which an employee identifies with the organization, its goals and expectations to maintain its communion with the 
organization [8], and the mental attitude that is reflected in the behavior actions of members of the organization [9]-[10]. Meanwhile, auditor independence is also a variable that gives effect to the implementation of good governance in addition to organizational commitment and independence in the mental attitude must be maintained by the auditor [11]. In addition, the definition of auditor independence is a freedom from pressure and other factors, indicated through certain activities or relationships including objectivity and integrity, while doing the auditing process [12]. Moreover, other factor of good governance is internal control. Internal control is an effort to protect institutional assets through a good control system. Internal control is any action taken by management to ensure the achievement of the goals and objectives of the organization. Internal control can also affect the reliability of financial statements and the effectiveness of all organizational activities [13]. In relation to organizational performance, it can be explained that internal control concerning the implementation of operational procedures in accordance with established guidelines, in which the division of functions, authority, and the use of documents and the determination of the flow of institutional activities. If the scope of internal control is done well, it is expected the activities in the institution will be more organized and procedural, so that will impact on the achievement in accordance with the target. Empirical studies have been conducted to show that internal control has a correlation with firm performance [14]. Ethical leadership also influences to the implementation of good governance in government institutions. The leader who has the function of influencing, coordinating, and giving instructions and delegates to subordinates must have morally and ethically acceptable behavior. In other words, leaders are required to apply an ethical leadership model based on concepts developed through social interaction with their staff [15]. Even though there is dynamic changing in public sector organization. However, processes of individual and organization improvement are rising up lately [16]. Thus, this study aims to empirically examine the effect of organizational commitment, auditor independence, internal control, and ethical leadership in good governance and organizational performance.

\section{METHODS}

A quantitative approach is used in this study by collecting primary data. The data analysis uses Partial Least Square (PLS) approaches. PLS is a model of Structural Equation Modeling (SEM) equations based on components or variants. PLS is an alternative approach that shifts from a Covarianbased SEM approach to a variance-based [17].

There are 90 respondents from 45 public organizations in Samarinda. There are criteria for respondents, such as selection of respondents in this study is the head of technical section each SKPD one person and one head section (Kasi). The reason of the respondent criteria is based on the knowledge held about the policies, programs and plans implemented by each SKPD up to the responsibility at the end of each budget year. In addition, they also understand the internal control system that exists within the organization and serve every inspection conducted by the inspectorate and the State Financial Auditor (BPK).

The variables in this study are classified into three variables: exogenous variable or independent variable which includes organizational commitment (X1), independence of auditor (X2), internal control (X3), and ethical leadership (X4); the first variable (intervening variable) namely good governance (Y1); and the second endogenous variable (dependent variable) is performance (Y2).

\section{RESULTS}

In calculating reliability these study using composite reliability, i.e if the value is greater than 0.7 is considered satisfactory. Based on the results of composite reliability testing in Table I shows that all the indicator blocks that measure the organizational commitment (X1), auditor independence (X2), internal control (X3), ethical leadership (X4), implementation of good governance (Y1), and SKPD performance (Y2) has a value of composite reliability> 0.7. It can therefore be stated that the indicators are believed to be able to measure the construct. 
TABLE I

TEST RELIABILITY in LATENT VARIABLES

\begin{tabular}{|l|l|}
\hline \multicolumn{1}{|c|}{ Latent Variable } & $\begin{array}{c}\text { Goodness of Fit } \\
\text { Composite Reliability }\end{array}$ \\
\hline Organizational Commitment (X1) & 0,810166 \\
\hline Independency Auditor (X2) & 0,793921 \\
\hline Internal Control (X3) & 0,875365 \\
\hline Ethical Leadership (X4) & 0,876315 \\
\hline Implementation of Good Governance (Y1) & 0,865498 \\
\hline Performance of SKPD (Y2) & 0,937992 \\
\hline Source: Data analyzes
\end{tabular}

Source: Data analyzes

From Table I, it turns out all the latent variables have a value greater than 0.70 so that the model in this study has met the composite reliability. It can be said that the instruments or questionnaires used in this study can measure consistently over time by using the same measuring instrument, the same research object and producing unequal results.

After validity and reliability tested on all latent variables which results valid and reliable results, the latent variable can be continued in the analysis with the diagram presented in Figure 1. Based on Figure 1, it can be interpreted each path coefficient. The path coefficients are hypothetical in this study, which can be presented in the following structural equations. The equations are detailed in Table II.
TABLE II

RESULT of COEFFICIENT TEST of PERFORMANCE MODEL of GOVERNMENT ORGANIZATIONS

\begin{tabular}{|c|c|c|c|c|}
\hline Variable & Coeff & t-Stat & $\begin{array}{c}\text { t- } \\
\text { tabel }\end{array}$ & $\begin{array}{l}\text { Hypothesis } \\
\text { Testing } \\
\text { Decision }\end{array}$ \\
\hline $\begin{array}{l}\text { Organizational } \\
\text { commitment (X1) to the } \\
\text { implementation of good } \\
\text { governance (Y1) }\end{array}$ & 0,203157 & 3,415646 & 1,96 & Significant \\
\hline $\begin{array}{l}\text { Independence of auditors } \\
\text { (X2) on the } \\
\text { implementation of good } \\
\text { governance (Y1) }\end{array}$ & 0,504613 & 5,258207 & 1,96 & Significant \\
\hline $\begin{array}{l}\text { Internal control (X3) on the } \\
\text { implementation of good } \\
\text { governance (Y1) }\end{array}$ & $-0,014049$ & 0,174323 & 1,96 & $\begin{array}{l}\text { Not } \\
\text { Significant }\end{array}$ \\
\hline $\begin{array}{l}\text { Ethical Leadership (X4) to } \\
\text { the implementation of } \\
\text { good governance (Y1) }\end{array}$ & 0,260984 & 3,133732 & 1,96 & Significant \\
\hline $\begin{array}{l}\text { Organizational } \\
\text { commitment (X1) to the } \\
\text { performance of SKPD } \\
(\mathrm{Y} 2)\end{array}$ & 0,590229 & 6,589904 & 1,96 & Significant \\
\hline $\begin{array}{l}\text { Independence of auditor } \\
(\mathrm{X} 2) \quad \text { on } \\
\text { performance }(\mathrm{Y} 2)\end{array}$ & $-0,057006$ & 0,672233 & 1,96 & $\begin{array}{l}\text { Not } \\
\text { Significant }\end{array}$ \\
\hline $\begin{array}{l}\text { Internal control (X3) on } \\
\text { SKPD performance }(Y 2)\end{array}$ & $-0,102712$ & 0,988195 & 1,96 & $\begin{array}{l}\text { Not } \\
\text { Significant }\end{array}$ \\
\hline $\begin{array}{l}\text { Ethical Leadership (X4) on } \\
\text { the performance of SKPD } \\
\text { (Y2) }\end{array}$ & $-0,089819$ & 0,854811 & 1,96 & $\begin{array}{l}\text { Not } \\
\text { Significant }\end{array}$ \\
\hline $\begin{array}{l}\text { Implementation of good } \\
\text { governance (Y1) on the } \\
\text { performance of SKPD } \\
\text { (Y2) }\end{array}$ & 0,427134 & 4,674702 & 1,96 & Significant \\
\hline
\end{tabular}

Based on Table II, the interpretation of each path coefficient is as follows: organizational commitment has a significant effect on the implementation of good governance with the direction of positive relationship. This can be seen from the coefficient of the path marked positive of 0.203157 with a $t$ value of statistics of 3.415646 greater than the value of $t$ table $=1.96$. Thus the organizational commitment has a significant effect on the implementation of good governance of 0.203157 .

Independence of auditors has a significant effect on the implementation of good governance with the direction of positive relations. This can be seen from the coefficient of the path marked positive 0,504613 with the value of $t$ statistics of 5.258207 larger than the value of $t$ table $=1.96$. Thus the independence of auditors significantly influences 
the implementation of good governance of 0,504613 .

Internal control does not significantly affect the implementation of good governance with the direction of negative relations. This can be seen from the coefficient of paths with negative sign of 0.014049 with a statistical $t$ value of 0.174323 smaller than the value of $\mathrm{t}$ table $=1.96$. Thus, internal control shows significant effect on the implementation of good governance of -0.014049 .

Ethical leadership has a significant effect on the implementation of good governance with the direction of positive relationships. This can be seen from the coefficient of the path marked positive of 0.2609819 with a statistical $t$ value of 3.133732 greater than the value of t table $=1.96$. Thus, ethical leadership has a significant effect on the implementation of good governance of 0.2609819.

Implementation of good governance significantly affects the performance of SKPD with positive relationship direction. This can be seen from the coefficient of the path marked positive of 0.427134 with a statistical $t$ value of 4.674702 greater than the value of $t$ table $=1.96$. Thus, organizational commitment has a significant effect on SKPD performance of 0.427134 .

\section{IV.DISCUSSION}

Implementation of good governance significantly affects the performance of SKPD with positive relationship direction.

\section{A. Organizational Commitment Influential Positive Significant Against the Implementation of Good Governance}

The commitment that exists within the organization has a significant influence on the implementation of the principles of good governance. Commitment formed within the organization is formed because of the high commitment of the employees in the organization to remain part of the organization where they work. High organizational commitment, especially from a leader will be able to encourage increased commitment from his subordinates, so that will be able to carry out the principles of good governance well. Based on the description can be concluded that organizational commitment affect on the implementation of good governance at SKPD in East Kalimantan Province is proven or supported by data.

This finding is reinforced by organizational commitment indicator (X1) which in this study consists of six (6) indicators can explain the influence of organizational commitment to the implementation of good governance. Of the six indicators that have the highest factor loading value is the assumption that the organization has a lot of meaning for personal employees (KO5) of 0.746 and loading value of the highest factor variable implementation of good governance is all public complaints on the service acted upon (IGG14) of 0.788. These findings prove that the higher the commitment of employees, the higher follow-up done by SKPD in handling complaints by the community about the services that have been done. The organization of the workplace may identify itself with the goals and values that exist within the organization, so that the employee will retain his/her association with the organization.

\section{B. Auditor Independence Positive Significant Influence against Good Governance Implementation}

The results of this study show that auditor independence has a significant positive effect on the implementation of good governance. These findings indicate that an auditor's independent attitude influences the implementation of good governance within the organization.

The independence of an auditor is important to do so that the auditor will not be affected and not influenced by the various forces that come from outside the auditor's self in considering the facts encountered in the examination or in conducting the audit. Because the more independent an auditor in conducting the examination, then the resulting audit results will be more objective. Through this objectivity SKPD will be audited to make efforts to comply with the guidelines and regulations in every activity, including in implementing the principles of good governance. Based on the description can be concluded that the independence of auditors affect the implementation of good governance at government organizations (SKPD) of East 
Kalimantan Province is proven or supported by the data.

These findings prove that the more objective audit results have been made, the faster the process of handling complaints by the public. In the Code of Ethics of Indonesian Accountants, in article 1, paragraph 2, which states that each member must maintain integrity, objectivity and independence in carrying out its duties. An auditor who upholds his or her independence will be unaffected and unaffected by external matters in considering the facts he or she encounters in the examination.

To assist in the creation of organizational independence, the audit institution shall carry out accountability and report the auditor's results on a regular basis to the highest officials of the relevant government entity and to the State Finance Auditor (BPK). In addition, the internal audit institution should be placed outside the line management function and staff of the audited entity. The auditors should be kept away from political pressure so that they can conduct the audit objectively, without fear due to political pressure. Therefore, an internal audit should be independent, since an internal audit function can be viewed as a "first line of defense" of adequate organizational governance in activity and financial reporting. Reference [18] shows that auditor independence has a positive influence with local government accountability. This result is also supported by [5] which stated that an independent audit committee is essential for good governance practice. Reference [19] found a relationship between the organization of companies reporting financial fraud with the incidence of lack of members of the independent audit committee.

\section{Internal Control No Significant Influence against the Implementation of Good Governance}

Internal control has no significant effect on the implementation of good governance. The results showed that the control that has been done in the organization does not affect the implementation of good governance. This indicates that the good in the implementation of the principles of good governance of government organizations (SKPD) does not have a close relationship with the implementation of internal controls in the organization. Based on the description can be concluded that internal control affect on the implementation of good governance in SKPD East Kalimantan Provincial Government is not proven or not supported by data.

This proves that the higher the supervision is, the more public complaints are not acted upon. SKPD focuses more on supervision, so that community service is neglected.

The lack of influence in these findings indicates that in government organizations, both central government and local government internal control functions of government organizations conducted by BPKP, Inspectorate and Regional Supervisory Board (BAWASDA) in practice, have not been able to carry out supervisory functions or examination to the fullest. This is due to several factors, among others, political factors and dominance of the head of the agency being examined. The same thing is done by members of DPR/D in conducting supervision of the executive.

The findings of this study do not support the empirical findings of research done by [20]-[21] and [22] which in the research proves that there is a relationship between internal control and good governance. In addition, reference [6] argues that control activities have a key role in ensuring the reliability and credibility of accounting information.

\section{Ethical Leadership Positive Influence Significant to the Implementation of Good Governance}

The results of this study indicate that ethical leadership has a significant positive effect on the implementation of good governance. These results indicate that ethical leadership styles can influence the implementation of good governance. Thus, a leader must be able to provide examples of good, ideal and ethical behavior to perform their main tasks and functions in the organization so as to influence the implementation of the organization based on the principle of good governance. A leader who possesses knowledge and ability so as to encourage the person he leads to participate in the completion of the task. Leadership skills and skills lead are important factors in the implementation of organizational governance practices. Based on the description can be concluded ethical leadership 
influence on the implementation of good governance at SKPD in East Kalimantan Province is proven or supported by data. The findings showed that if the leader always coordinate all activities from various structural levels, the faster the process of handling complaints by the public.

Ethical leaders will be able to influence the implementation of good governance in government institutions. This is because a leader has the function of influencing, co-coordinating, and giving instructions and delegates to subordinates. Therefore, the leadership must have morally and ethically acceptable behavior, so that the organization can run well without any moral, social, and ethical violations. Reference [15] states that a leader is required to apply an ethical leadership model, ie leadership based on concepts developed through social interaction with his followers. Thus leadership factors of various levels greatly influence the application of organizational governance practices based on the principles of good governance.

\section{E. Implementation of Good Governance Influence Positive Significant To Organizational Performance}

The results of this study indicate that the implementation of good governance that refers to the principles of good governance can encourage the achievement of SKPD organizational performance as expected by the principal (community). Thus, success in improving the performance of the organization one of them is to implement the principles of good governance. Implementation of principles of good governance in government organizations (SKPD) will encourage the improvement of the organization's performance. This is possible because every employee/officer involved in the organization will endeavor to comply with the norms, regulations in performing its duties and functions. They strive to provide services, and use the resources of the government organizations (SKPD) in accordance with the standards.

Based on the information and the results can be concluded that the implementation of good governance affects the performance at SKPD in
East Kalimantan Province is proven or supported by data.

\section{CONCLUSIONS}

To strengthening public sector organization, it needs good governance, organizational commitment, through ethical leadership. From individual aspect, staff have important role in leadership and governance as two aspects of organizational commitment.

Organizational commitment affect the implementation of good governance in government organizations (SKPD) in East Kalimantan Province. The independence of the auditor influences the implementation of good governance in SKPD East Kalimantan Provincial Government. Ethical leadership affects the implementation of good governance at SKPD in East Kalimantan Province. It means a leader who is able to provide examples of good, ideal and ethical behavior to carry out their main tasks and functions within the organization will be able to influence the implementation of the organization based on the principle of good governance. As a result, the success of implementation of good governance can affect the performance improvement at SKPD in East Kalimantan Province. These can indicate that success in improving the individual performance can improve of one of the organizations is to implement the principles of good governance.

\section{REFERENCES}

[1] Bastian, Indra. (2006). Akuntansi Sektor Publik: Suatu Pengantar. Jakarta: Penerbit Erlangga.

[2] Chaudhry, Imran Sharif. Shahnawaz, Malik. Khurram, Nawaz Khan. and Sohail, Rasool. (2009). Factors Affecting Good Governance in Pakistan: AnEmpirical Analysis. European Journal of Scientific Research, 35 (3), 337-346.

[3] Santiso, Carlos. (2001). Good Governance and Aid Effectiveness:The World Bank and Conditionality. The Georgetown Public Policy Review, 7 (1) Fall, 1-22.

[4] Bridgman, Peter. (2007). Performance, Conformance, and Good Governance in thePublic Sector. Key Issues Risk Management, April, Keeping Good Companies, 149-157.

[5] Sori, Muhamad Zulkarnain. Ramadili, S.M. and Karbhari, Yusuf. (2008) Audit Committee and Auditor Independence: The Bankers' Perception. Universiti Putra Malaysia. Cardiff University

[6] Danescu, Tatiana. (2011). Internal Control Activities: Cause And Effect Of A Good Governance Of Accounting Reportings And Fiscal Declarations. Annals Universitatis Apulensis Series Oeconomica.

[7] Mathis, Robert L. and John H. Jackson. (2007). Human Resource Management. Penerbit Cengage Learning: Edisi 12.

[8] Robbins, Stephen P. dan Timothy A. Judge. 2007. Organizational Behavior. Upper Saddle River, New Jersey: Pearson Education Inc: Twelfth Edition. 
[9] Mowday, R, Steers, R., and Porter, L. (1979). The measurement of organization commitment. Journal of Vocational Behavior 14, 224-247.

[10]Allen, Natalie J. and John, P. Meyer. (1990). The Measurement and Antecedents of Affective, Continuance and Normative Commitment to the Organization. Journal of Occupational Psychology 63, 1-18.

[11]Lawalata, Josina. Said, Darwis. and Mediaty. (2011). Influence of Auditor Independency, Organizational Commitment, Style of Organizational Culture and Leadership To Auditor Performance (Empirical Study at Office of Public Accountant in Makassar). Reporsitory Universitas Pendidikan Indonesia.

[12]Hendrikse, John W. and Leigh, Hendrikse. (2008). Business Governance Handbook: Principles and Practices. Cape Town: Juta \& Co, Ltd.

[13] Kagermann, Henning. William, Kinney. Karlheinz, Küting. dan ClausPeter, Weber. (2008). Internal Audit Handbook: Management with the SAP-Audit Roadmap. Berlin, Heidelberg: Springer - Verlag.

[14]Arosa. (2012). The Role of Board Structure as an internal control mechanism in non-listed firms. University of the Basque Country, UPV/EHU Avda. Lehendakari Agirre. 83 (48015), Bilbao, Vizcaya, Spain.

[15]Akker, Lenny Van Den. Heres, Leonie Karin Lasthuizen. Frederique, Six. (2009) Ethical Leadership and Trust; Its All About Meeting Expectation, International Journal of Leadership Studies, 5 (2).

[16]Rantelangi, Cornelius. (2014). Pengaruh Komitmen Organisasi, Independensi Auditor, Pengendalian Internal dan Kepemimpinan Etikal Terhadap Penerapan Good Governace dan Kinerja Satuan Kerja Perangkat Daerah (SKPD) Pada Provinsi Kalimantan Timur. Dissertation. Program Doktor Ilmu Ekonomi. Surabaya, Fakultas Ekonomi dan Bisnis. Universitas Airlangga.

[17] Ghozali, Imam. (2011), Structural Equation Modeling Metode Alternatif dengan Partial Least Square (PLS). Semarang, Badan Penerbit Universitas Diponegoro.

[18] Yang, Suchang. Jason, Zezhong Xiao. and Maurice, Pendlebury. (2008). Government Auditing in China: Problems and Reform. Advances in Accounting, Incorporating Advances in International Accounting, 24, 119-127.

[19]Beasley, Mark. S., Carcello, Joseph V., Hermanson, Dana R., and Lapides, Paul D. (2000). Fraudulent Financial Reporting: Consideration of Industry Traits and Corporate Governance Mechanisms. Accounting Horizons 14 (4), 441-454.

[20] Pratolo, Suryo. (2007). Good Corporate Governance dan Kinerja BUMN Di Indonesia: Aspek Audit Manajemen dan Pengendalian Intern sebagai Variabel Eksogen serta Tinjauannya pada Jenis Perusahaan. Pascasarjana Universitas Muhammadiah Yogyakarta.

[21] Pratolo, Suryo. (2008). Pengaruh Audit Manajemen, Komitmen Organisasional Manajer, Pengendalian Intern terhadap Penerapan Prinsip-Prinsip Good Corporate Governance dan Kinerja BUMN di Indonesia. Jurnal Akuntansi dan Investasi, Vol. IX, 1, 15-32.

[22] Fadilah, Sri. (2011). Analisis Penerapan Good Governance Dilihat dari Implementasi Pengendalian Intern dan Total Quality Management. Prosiding SNA PP2011 Sosial, Ekonomi, dan Humaniora, 1 (1), 387-400. 